\title{
Peranan Inkubator Bisnis dalam Menumbuhkan Jiwa Kewirausahaan Mahasiswa Akademi Komunitas Negeri Putra Sang Fajar Blitar
}

\author{
Mohamad Ardiansyah 1, Nunuk Latifah 2, dan Anna Widayani 3 \\ 1 Akademi Komunitas Negeri Putra Sang Fajar Blitar \\ Jl. Tanjung no 1, Blitar kota kode pos \\ e-mail: ardiansyakh12@gmail.com1, nunuklatifah76@gmail.com2, annawidayani@akb.ac.id3
}

\begin{abstract}
Abstrak - Inkubator Bisnis Teknologi (IBT) merupakan program untuk menumbuhkembangkan kewirausahaan yang berbasis teknologi berupa pendanaan, pelatihan, dan asistensi bagi inkubator dan tenant (pengusaha pemula) yang dilaksanakan melalui sistem kompetisi/seleksi. Sebagaimana perguruan tinggi lain di Indonesia yang menyelenggarakan mata kuliah kewirausahaan, tantangan yang dihadapi Akademi Komunitas Negeri Putra Sang Fajar Blitar (AKB) adalah menyediakan sebuah fasilitas yang dapat membantu melahirkan wirausahawan yang tidak hanya memahami teori dan konsep bisnis serta berhasil menghasilkan konsep produk, akan tetapi juga memfasilitasi dan mendampingi pendirian usaha yang dirintis oleh mahasiswa.. Metode yang digunakan dalam penelitian ini menggunakan deskriptif dengan pendekatan kualitatif. Teknik pengumpulan data dalam penelitian ini menggunakan wawancara dengan pembina Inkubator Bisnis, anggota Inkubator Bisnis, dan mahasiswa AKB serta dokumentasi berupa gambar dan audio. Hasil penelitian menunjukkan kegiatan Inkubator Bisnis dalam menumbuhkan jiwa kewirausahaan adalah pelatihan dan pembinaan serta pembentukan unit bisnis. Dalam usaha menumbuhkan jiwa kewirausahaan mahasiswa Akademi Komunitas Negeri Putra Sang Fajar Blitar beberapa cara sudah dilakukan. Dalam menjalankan kegiatannya, inkubator bisnis di kampus Akademi Komunitas Negeri Putra Sang Fajar Blitar tak lepas dari kendala yang berasal dari faktor internal maupun faktor eksternal.
\end{abstract}

Kata kunci : jiwa kewirausahaan, Inkubator Bisnis

\begin{abstract}
Technology Business Incubator (IBT) is a program to develop technology-based entrepreneurship in the form of funding, training, and assistance for incubators and tenants (novice entrepreneurs) which are implemented through a competition / selection system. As with other tertiary institutions in Indonesia that conduct entrepreneurship courses, the challenge faced by the Putra Sang Fajar Blitar Academy (AKB) is to provide a facility that can help give birth to entrepreneurs who not only understand business theories and concepts and successfully produce product concepts, but also facilitates and accompanies the establishment of businesses pioneered by students. The method used in this study uses descriptive qualitative approaches. Data collection techniques in this study used interviews with Business Incubator coaches, Business Incubator members, and AKB students as well as documentation in the form of images and audio. The results showed that the Business Incubator activity in fostering an entrepreneurial spirit was training and coaching as well as the formation of business units. In an effort to grow the entrepreneurial spirit of Academy students, some methods have been done. In carrying out its activities, the business incubator on the campus of Putra Sang Fajar Academy can not be separated from obstacles originating from internal and external factors.
\end{abstract}

Keywords：entrepreneurial spirit, Business Incubator

\section{PENDAHULUAN}

Inkubator Bisnis Teknologi (IBT) merupakan program yang dikelola oleh Direktorat Perusahaan Pemula Berbasis Teknologi pada Kementerian Riset, Teknologi, dan Pendidikan Tinggi. Program ini ditunjukkan untuk menumbuhkembangkan kewirausahaan yang berbasis teknologi. Program IBT diwujudkan dalam bentuk instrumen kegiatan berupa pendanaan, pelatihan, dan asistensi bagi inkubator dan tenant (perusahaan pemula) yang dilaksanakan melalui sistem kompetisi/seleksi. Menurut Hewick (2006) Inkubator adalah "ruang kerja khusus (gedung) untuk mendukung bisnis yang memenuhi syarat dengan: bimbingan, pelatihan, jaringan profesional, bantuan dalam hal keuangan sampai mereka dinyatakan lulus dan dapat bertahan dalam lingkungan yang 
kompetitif'. Jadi Inkubator Bisnis merupakan suatu tempat yang menyediakan fasilitas dalam percepatan penumbuhan kewirausahaan melalui sarana dan prasarana yang dimiliki sesuai dengan kompetensi dasarnya. Adapun landasan hukumnya pada Inkubator Bisnis ini adalah Peraturan Presiden No. 27 tahun 2013 tentang Pengembangan Inkubator Wirausaha dan Peraturan Menteri Koperasi dan UKM No. 24 Tahun 2015 tentang NSPK (Norma, Standar, Prosedur, dan Kriteria) Inkubator Wirausaha.

Inkubator Bisnis menjadi sebuah kebutuhan yang strategis bgi perguruan tinggi yang menyelenggrkan mata kuliah kewirausahaan. Hal ini dikarenakan arah dari learning outcome pada mata kuliah ini, bukan hanya agar terbentuk perilaku dan karakter wirausaha pada diri mahasiswa, akan tetapi lebih jauh lagi adalah terlahir wirausaha muda yang dapat menggerakkan perekonomian bangsa. Kegiatan dari Inkubator Bisnis ini sendiri antara lain : pengembangan jiwa kwirausahaan, pelatihan manajemen dan skills usaha bagi tenant, konsultasi bisnis,peninjauan di perusahaan yang sudah mapan serta menfasilitasi tenant dalam berwirausaha untuk menghasilkan wirausaha baru. Sebagaimana diyakini, wirausahawan (entrepreneur) memiliki peran strategis dalam kemajuan suatu bangsa. Di negara-negara maju, wirausahawan merupakan tulang punggung penggerak perekonomian nasional. Di Indonesia sendiri, Global Entrepreneurship Program Indonesia atau disingkat dengan GEPI merupakan salah satu organisasi yang memiliki kepedulian terhadap iklim kewirausahaan di Indonesia dan mampu mencetak banyak wirausaha muda lewat program inkubator bisnisnya. Sebagaimana perguruan tinggi lain di Indonesia yang menyelenggarakan mata kuliah kewirausahaan, tantangan yang dihadapi Akademi Komunitas Negeri Putra Sang Fajar Blitar adalah menyediakan sebuah fasilitas yang dapat membantu melahirkan wirausahawan yang tidak hanya memahami teori dan konsep bisnis serta berhasil menghasilkan konsep produk, akan tetapi juga memfasilitasi dan mendampingi pendirian usaha yang dirintis oleh mahasiswa.

Sejalan dengan visi dan misi Akademi Komunitas Negeri Putra Sang Fajar Blitar, Inkubator Bisnis di Akademi Komunitas Negeri Putra Sang Fajar Blitar bertujuan mengembangkan jiwa kewirausahaan khususnya di kalangan mahasiswa yang ditunjukkan dengan adanya kegiatan-kegiatan yang bisa menampung potensi-potensi yang dimiliki mahasiswa di setiap program studi. Berdasarkan Permendikbud No. 156 Tahun 2014 tentang Pendirian, Organisasi, dan Tata Kerja Akademi Komunitas Negeri Putra Sang Fajar Blitar, program studi yang ada di Akademi Komunitas Negeri Putra Sang Fajar Blitar adalah :

1.Program Studi Administrasi Server dan Jaringan Komputer

2.Kekhususan Otomasi Perkantoran

3.Program Studi Penyuntingan Audio dan Video

4.Kekhususan Program Studi Digital Arsitektur

5.Pengolahan Hasil Ternak Unggas

Dengan adanya Inkubator Bisnis diharapkan bisa menjadi salah satu alat untuk menyiapkan mahasiswa terjun ke dalam dunia bisnis yang sebenarnya.

Keberadaan Inkubator Bisnis di kalangan mahasiwa Akademi Komunitas Negeri Putra Sang Fajar Blitar masih belum bisa dimanfaatkan secara optimal. Masih banyak mahasiswa yang belum mengerti/paham tentang manfaat dan fungsi dari Inkubator Bisnis. Hal itu disebabkan oleh banyak hal, yaitu:(1) kurangnya sosialisasi tentang manfaat, fungsi dan kegiatan-kegiatan yang akan dilakukan dalam Inkubator Bisnis bagi mahasiswa, (2) kurangnya dukungan dan motivasi dari pihak kampus, misalnya dari dosen pembimbing, pembina, pengurus, dll, (3) kurangnya sarana dan prasarana pendukung, (4) masih kurangnya pihak dunia usaha yang bisa diajak kerjasama untuk membina, melatih, menilai ataupun menggunakan hasil dari kegiatan mahasiswa, sehingga hanya sebagian mahasiswa saja yang tertarik dan bergabung dalam kegiatan Inkubator Bisnis di Akademi Komunitas Negeri Putra Sang Fajar Blitar.

Berdasarkan latar belakang diatas, penulis tertarik mengambil judul tentang : "Peranan Inkubator Bisnis Dalam Menumbuhkan Jiwa Kewirausahaan di Kalangan Mahasiswa Akademi Komunitas Negeri Putra Sang Fajar Blitar".

\section{STUdI PUSTAKA}

Pengertian Peranan

Berdasarkan Kamus Besar Bahasa Indonesia, peranan adalah tindakan yang dilakukan oleh seseorang dalam suatu peristiwa. Sedangkan menurut Soekanto (2006:212), peranan (role) merupakan aspek dinamis kedudukan (status). Apabila seseorang melaksanakan hak dan kewajibannya sesuai dengan kedudukannya, dia menjalankan suatu peranan. Pembedaan antara kedudukan dengan peranan adalah untuk kepentingan ilmu pengetahuan. Keduanya tak dapat dipisah-pisahkan karena yang satu tergantung pada yang lain dan sebaliknya. Tak ada peranan tanpa kedudukan atau kedudukan tanpa peranan. Setiap orang mempunyai macam-macam peranan yang berasal dari pola-pola pergaulan hidupnya. Hal itu sekaligus berarti bahwa peranan menentukan apa yang diperbuatnya bagi masyarakat serta kesempatankesempatan apa yang diberikan oleh masyarakat kepadanya.

Berdasarkan dua pengertian diatas dapat disimpulkan bahwa peranan adalah suatu tindakan seseorang terhadap cara menentukan sikap dan perbuatan dalam suatu situasi tertentu sesuai dengan kedudukan sosialnya.

\section{Pengertian Inkubator Bisnis}

Menurut Buku Panduan Inkubasi Bisnis Teknologi tahun 2017, Inkubator Bisnis adalah proses untuk mendukung pengembangan produk dan/atau pengembangan bisnis perusahaan pemula berbasis teknologi agar dapat menjadi perusahaan yang profitable memiliki pengelolaan organisasi dan keuangan yang benar, serta menjadi perusahaan yang sustainable, hingga memiliki dampak positif bagi masyarakat. Adapun tujuan dan sasaran pelaksanaan Inkubator Bisnis, yaitu:

1. Program ini bertujuan untuk :

a. Mendorong komersialisasi hasil inovasi teknologi dalam negeri.

b. Menumbuhkembangkan perusahaan pemula berbasis teknologi (PPBT).

2. Sasaran yang ingin dicapai adalah :

a. Terwujudnya komersialisasi inovasi teknologi yang berasal dari masyarakat, umum, LPK/LPNK/Balitbang/Dinas. 


\author{
b. Terwujudnya perusahaan pemula berbasis \\ teknologi.
}

\section{Cara Menumbuhkan Jiwa Kewirausahaan}

Menurut Maryanti, dkk (2017:181-182) beberapa usaha atau teknik, strategi yang perlu diterapkan dalam meningkatkan minat dan kegiatan kewirausahaan bagi mahasiswa, yaitu :

1. Pembentukan pusat studi kewirausahaan kampus.

2. Mata kuliah kewirausahaan dijadikan mata kuliah MKDU (Mata Kuliah Dasar Umum)

3. Menganggap penting kewirausahaan di kampus dan menjadikan mata kuliah kewirausahaan sebagai hal yang harus diberikan kepada mahasiswa.

4. Memaksimalkan dalam memanfaatkan program kewirausahaan yang digagas oleh lembaga pemerintah melalui pendidikan tinggi.

5. Perguruan tinggi harus mempersiapkan tenaga pendidik atau dosen yang mampu menginspirasi dan memotivasi mahasiswa menjadi SDM yang mandiri.

6. Program peningkatan dosen sebagai tenaga pendidik dapat dilakukan dengan melalui berbagai cara.

7. Mengembangkan kurikulum berbasis wirausaha.

8. Menjalin kerjasama dengan lembaga usaha.

9. Membuat kebijakan harus sudah memiliki usaha sebagai syarat kelulusan mahasiswa.

\section{Indikator Jiwa Kewirausahaan}

Menurut Suryana dalam Titiani (2014:11), ciri-ciri orang yang memiliki jiwa kewirausahaan adalah :

1. Penuh percaya diri, indikatornya adalah penuh keyakinan, optimis, berkomitmen, disiplin, dan bertanggung jawab.

2. Memiliki inisiatif, indikatornya adalah penuh energi, cekatan dalam bertindak, dan aktif.

3. Memiliki motif berprestasi, indikatornya adalah orientasi pada hasil dan wawasan ke depan.

4. Memiliki jiwa kepemimpinan, indikatornya adalah berani tampil beda, dapat dipercaya, dan tangguh dalam bertindak.

5. Berani mengambil resiko dengan penuh tantangan.

\section{MetODE}

\section{A. Jenis Penelitian}

Jenis penelitian yang digunakan dalam penelitian ini adalah deskriptif dengan pendekatan kualitatif, artinya penelitian yang berusaha mendeskripsi dan menginterpretasi kondisi atau hubungan yang ada, pendapat yang sedang tumbuh, proses yang sedang berlangsung, akibat yang sedang terjadi atau kecenderungan yang tengah berkembang (Sumanto dalam Dasim, 2012:79)

Menurut Dantes (2012:51), penelitian deskriptif diartikan sebagai suatu penelitian yang berusaha mendeskripsikan suatu fenomena/peristiwa secara sistematis sesuai dengan apa adanya. Penelitian deskriptif dilakukan untuk memperoleh informasi mengenai keadaan saat ini.

Penelitian ini menjelaskan peranan Inkubator Bisnis dalam menumbuhkan jiwa kewirausahaan di kalangan mahasiswa Akademi Komunitas Negeri Putra Sang Fajar Blitar.

\section{B. Teknik Analisa Data}

Menurut Miles dan Huberman, terdapat tiga teknik analisis data kualitatif yaitu reduksi data, penyajian data, dan penarikan kesimpulan. Proses ini berlangsung terusmenerus selama penelitian berlangsung, bahkan sebelum data benar-benar terkumpul.

1. Reduksi data

Reduksi data adalah bentuk analisis yang menajamkan, menggolongkan, mengarahkan, membuang yang tidak perlu dan mengorganisir data sedemikian rupa sehingga kesimpulan akhir dapat diambil. Reduksi tidak perlu diartikan sebagai kuantifikasi data.

2. Penyajian data

Penyajian data adalah kegiatan ketika sekumpulan informasi disusun, sehingga memberi kemungkinan akan adanya penarikan kesimpulan. Bentuk penyajian data kualitatif berupa teks naratif (bentuk catatan lapangan), matriks, grafik, jaringan dan bagan.

3. Penarikan kesimpulan

Penarikan kesimpulan adalah hasil analisis yang dapat digunakan untuk mengambil tindakan.

\section{HASIL DAN PEMBAHASAN}

Sesuai dengan tujuan pendirian Inkubator Bisnis di Akademi Komunitas Negeri Putra Sang Fajar Blitar, Inkubator Bisnis di Akademi Komunitas Negeri Putra Sang Fajar Blitar sudah berjalan walaupun masih belum maksimal. Adapun kegiatan Inkubator Bisnis yang sudah dilakukan di Akademi Komunitas Negeri Putra Sang Fajar Blitar adalah :

\section{Pelatihan dan Pembinaan}

Dalam upaya menumbuhkan jiwa kewirausahaan di kalangan mahasiswa Akademi Komunitas Negeri Putra Sang Fajar, inkubator bisnis memiliki peran sebagai wadah pelatihan dan pembinaan bagi mahasiswa ataupun alumni semua jurusan untuk siap kerja diluar maupun membuka usaha sendiri. Menurut Agustina (2011), pelatihan ditunjukan untuk membentuk dan mengembangkan sikap dan perilaku 'entrepreneur', mampu berkreasi, mampu menciptakan inovasi dan proaktif dalam menghadapi perkembangan lingkungan dan pasar. Pelatihan bagi tenant sebagai pengusaha pemula bersifat terapan, artinya ada kaitannya dengan bidang usaha dimana dia bekerja serta memberikan manfaat instan (instant benefit) artinya dapat memberi manfaat langsung. Agar tenant dapat mengaplikasikan keterampilan di tempat praktik, mengetahui dan menyesuaikan keterampilan yang dimiliki dengan kondisi nyata dalam praktik, sehingga dapat diketahui kendala/kesulitan yang ditemukan dalam praktik kerja maka setelah perlatihan dapat dilengkapi dengan pemagangan. Bentuk teknis dari pemagangan yang diterapkan adalah pengiriman individu dan/atau kelompok pada usaha-usaha kecil, menengah, dan sudah bersumber daya. Sedangkan pembinaan bertujuan untuk membantu memecahkan masalah yang dihadapi oleh tenant sehubungan dengan 
bisnisnya. Sifat bantuannya adalah konsultasi yang dilakukan secara berkesinambungan dengan memegang prinsip manajemen kewirausahaan.

Pelatihan dan pembinaan yang sudah dilakukan Inkubator Bisnis yang ada di Akademi Komunitas Negeri Putra Sang Fajar Blitar :

A. Bagi Anggota Inkubator Bisnis

a. Pelatihan

1.Pelatihan fotografi dalam mensponsori kegiatan Campus Expo yang diadakan oleh Keluarga Mahasiswa Panataran Blitar (KEMAPATA) selama 2 hari.

2. Desain konsep pembuatan buku tahunan sekolah di SMAN 1 Talun selama 1 hari.

b. Pembinaan

1. Konsultasi kepada pembina dalam hal videografi pada suatu event. Seperti bersih desa di Kelurahan Turi dan kunjungan industri yang dilaksanakan oleh kampus $\mathrm{AKB}$ selama 7 hari.

2. Membuat konsep desain suatu event seperti pembuatan logo Diesnatalis AKB selama 2 hari.

\section{B. Bagi Mahasiswa AKB}

Mengikutsertakan mahasiswa prodi PAV dalam suatu event/project inkubator bisnis khususnya dalam hal fotografi dan videografi peresmian Kampung Batik di Kelurahan Turi selama 2 hari.

\section{Pembentukan Unit Bisnis}

Inkubator bisnis berperan dalam mengarahkan dan membimbing proses penyelenggaraan usaha atau unit dari suatu organisasi bisnis yang dibentuk. Bentuk teknisnya adalah pendampingan dalam bentuk menyalurkan setiap job yang diterima sesuai dengan unit usaha yang sudah dibentuk setiap prodi dalam kampus Akademi Komunitas Negeri Putra Sang Fajar Blitar yang terselenggara atas dasar kebutuhan atau permintaan.

Selama ini setiap ada job, pengerjaan langsung ditangani secara bersama oleh anggota inkubator bisnis Seharusnya setiap program studi memiliki unit bisnis yang sesuai keterampilan yang dimiliki program studi masing-masing, sehingga pengerjaannya lebih teliti dan tidak terkesan asal-asalan.

\section{Menumbuhkan Jiwa Kewirausahaan Pada Mahasiswa Akademi Komunitas Negeri Putra Sang Fajar Blitar}

Setiap kurikulum maupun kompetensi lulusan pada semua jurusan yang ada di Akademi Komunitas Negeri Putra Sang Fajar Blitar memiliki tujuan untuk menjadikan mahasiswa mempunyai jiwa kewirausahaan. Hal ini di tunjang dengan adanya mata kuliah kewirausahaan pada masing-masing program studi, dengan tujuan agar dapat mencapai kompetensi lulusan yang inovatif, kreatif, penuh percaya diri, memiliki inisiatif membuka usaha sendiri, memiliki motif berprestasi, memiliki jiwa kepemimpinan, dan berani mengambil resiko dengan penuh tantangan.

Menurut Maryanti, dkk (2017:181-182) beberapa usaha atau teknik, strategi yang perlu diterapkan dalam meningkatkan minat dan kegiatan kewirausahaan bagi mahasiswa, yaitu :

1. Pembentukan pusat studi kewirausahaan kampus.
Dengan dibuatnya Unit Bisnis di setiap prodi di kampus Akademi Komunitas Negeri Putra Sang Fajar Blitar. Seperti halnya Prodi Otomasi Perkantoran membuat suatu usaha Tour Guide maupun sebagai Event Organizer prodi Penyuntingan Audio Video bisa membuat usaha studio foto mini maupun percetakan, prodi Administrasi Server dan Jaringan Komputer bisa membuat usaha desainer web maupun konsultan TI.

2. Mata kuliah kewirausahaan dijadikan mata kuliah MKDU (Mata Kuliah Dasar Umum), dalam pelaksanaannya mata kuliah kewirausahaan di AKB prosentase masih banyak dalam hal teori sehingga kemampuan mahasiswa dalam berwirausaha masih minim.

3. Menganggap penting kewirausahaan di kampus dan menjadikan mata kuliah kewirausahaan sebagai hal yang harus diberikan kepada mahasiswa. Dari hasil wawancara mahasiswa perwakilan setiap prodi jiwa kewirausahaan yang dimiliki hanya sebatas ide dan keinginan.

Menurut jawaban responden :

"Sangat berminat. Siapa sih yang tidak mau berwirausaha setiap orang tentu ingin berwirausaha daripada kita bekerja untuk orang lain, lebih baik kita menciptakan lapangan perkerjaan untuk orang lain". (wawancara tanggal 27 Mei 2019)

4.Memaksimalkan dalam memanfaatkan program kewirausahaan yang digagas oleh lembaga pemerintah melalui pendidikan tinggi. Seperti program Inkubator Bisnis yang sudah dicanangkan oleh Kementerian Riset Teknologi dan Pendidikan Tinggi.

5.Perguruan tinggi harus mempersiapkan tenaga pendidik atau dosen yang mampu menginspirasi dan memotivasi mahasiswa menjadi SDM yang mandiri. Masih minim kemampuan dan pengetahuan dari tenaga pendidik dalam hal pengembangan kurikulum kewirausahaan.

6.Program peningkatan dosen sebagai tenaga pendidik dapat dilakukan dengan melalui berbagai cara. Selama ini belum ada pelatihan khusus untuk meningkatkan kompetensi dosen dalam hal kewirausahaan.

7.Mengembangkan kurikulum berbasis wirausaha. Perlu adanya pengembangan kurikulum berbasis wirausaha.

8. Menjalin kerjasama dengan lembaga usaha. Mulai terjalin kerjasama dengan lembaga usaha masyarakat dalam bentuk kegiatan Pengabdian Kepada Masyarakat

9. Membuat kebijakan harus sudah memiliki usaha sebagai syarat kelulusan mahasiswa. Selama pelaksanaannya masih belum ada kebijakan dari kampus AKB.

Kewirausahaan merupakan suatu kemampuan kreatif dan inovatif yang menjadikan kiat, dasar, sumber daya, proses dan perjuangan untuk menciptakan nilai tambah barang dan jasa yang dilakukan dengan keberanian untuk menghadapi risiko. Jiwa kewirausahaan bisa ditumbuhkan pada seseorang melalui banyak hal, salah satunya melalui pendidikan. Pendidikan kewirausahaan diharapkan mampu merangsang minat atau keinginan seseorang sehingga tumbuhlah jiwa kewirausahaan pada orang tersebut.

Usaha yang sudah dilaksanakan kampus AKB guna menumbuhkan jiwa kewirausahaan di kalangan mahasiswa, diantaranya :

1.Dicanangkannya program inkubator bisnis sebagai sarana/wadah para mahasiswa untuk mengembangkan 
potensi mereka, agar siap bekerja mandiri/wirausaha maupun bekerja diluar.

2.Dilaksanakan lomba ide usaha untuk mahasiswa semua prodi yang pemenangnya diberikan dana dan pelatihan usaha oleh kampus untuk mengembangkan usaha.

Kendala yang Dihadapi Inkubator Bisnis Dalam Menumbuhkan Jiwa Kewirausahaan pada Mahasiswa Akademi Komunitas Negeri Putra Sang Fajar Blitar

Dari pernyataan diatas, dalam menjalankan kegiatannya Inkubator Bisnis tidak lepas dari permasalahan ataupun kendala. Kendala-kendala itu bisa berasal dari faktor internal maupun faktor eksternal. Kendala dari faktor internal adalah :

1.Manajemen SDM dari Inkubator Bisnis masih belum baik. Karena anggota inkubator bisnis banyak yang sudah bekerja. Sehingga jika ada job yang diterima langsung ditangani Inkubator Bisnis secara serabutan. Dengan solusi, setiap prodi membuat suatu unit usaha yang dinaungi oleh inkubator bisnis sehingga mahasiswa lebih fokus ke prodi ditekuninya.

2.Soft skill (bakat) maupun hard skill (keterampilan teknis) masih belum maksimal.

3.Belum mempunyai mesin cetak karena setiap job yang diterima berkaitan dengan desain dan cetak, sehingga dalam percetakan dilimpahkan ke pihak luar.

4.Kurangnya pelatihan dan pembinaan dari pihak kampus ataupun dari pihak yang lebih mengerti Inkubator Bisnis.

5.Masih kurangnya pengalaman dalam hal berbisnis.

6.Masih kurangnya sumber dana.

Menurut Pembina Inkubator Bisnis mengatakan bahwa :

"Mahasiswa AKN Blitar itu sebagian besar adalah karyawan yang bekerja di luar kampus. Jadi ketika ada inkubator bisnis di kampus mahasiswa belum bisa membagi waktu antara tugas di kampus/inkubator dengan pekerjaan yang dijalaninya. Jadi sepertinya mereka masih repot membagi waktunya”. (wawancara tanggal 25 Maret 2019)

Menurut Rizal Zulfikar selaku anggota Inkubator Bisnis :

"Mungkin ketersediaan alat yang masih terbatas dan masih adanya perbedaan pendapat di kalangan mahasiswa yang belum bisa menggabungkan ide-ide mereka dan belum bisa merealisasikan". (wawancara tanggal $27 \mathrm{Mei}$ 2019)

Sedangkan kendala dari faktor eksternal :

1. Kurangnya kemitraan bisnis.

2.Promosi yang masih kurang.

3.Program Inkubator Bisnis masih belum begitu dikenal di lingkungan kampus maupun luar kampus.

4. Kredibilitas Inkubator Bisnis yang masih kurang di mata pengguna/konsumen.

Kendala Inkubator Bisnis dalam menumbuhkan jiwa kewirausahaan di kalangan mahasiswa Akademi Komunitas Negeri Putra Sang Fajar Blitar adalah :

1.Kurangnya pelatihan dan pembinaan sehingga mahasiswa mencari dan memecahkan masalah sendiri. Solusi untuk kendala ini adalah setiap kegiatan diagendakan untuk melakukan pertemuan yang berkaitan tentang pengetahuan usaha, motivasi, maupun cara membuka usaha.

2.Setiap mahasiswa diwajibkan ikut program Inkubator Bisnis agar mahasiswa mempunyai pengalaman untuk membuka dan menjalankan usaha.Hasil penelitian dibahas dan dibandingkan dengan hasil penelitian dari artikel yang diacu, jika mungkin.

\section{KESIMPULAN}

Berdasarkan hasil penelitian menggunakan metode deskriptif kualitatif dengan teknik observasi dan wawancara yang dilaksanakan di Al Fariq Multimedia "Inkubator Bisnis Akademi Komunitas Negeri Putra Sang Fajar Blitar" dapat diambil kesimpulan bahwa sesuai dengan data yang diperoleh peneliti, Inkubator Bisnis kampus Akademi Komunitas Negeri Putra Sang Fajar Blitar sudah berjalan walaupun masih belum maksimal. Kegiatan Inkubator Bisnis dalam menumbuhkan jiwa kewirausahaan di kalangan mahasiswa Akademi Komunitas Negeri Putra Sang Fajar Blitar berupa Pelatihan dan Pembinaan, pembentukan Unit Bisnis. Dalam usaha menumbuhkan jiwa kewirausahaan mahasiswa Akademi Komunitas Negeri Putra Sang Fajar Blitar beberapa cara sudah dilakukan seperti membuat event wirausaha, dicanangkannya program inkubator bisnis, dan mewajibkan mahasiswa AKB ikut program inkubator bisnis. Inkubator bisnis di kampus Akademi Komunitas Negeri Putra Sang Fajar Blitar tak lepas dari kendala yang berasal dari faktor internal maupun faktor eksternal. Sedangkan kendala dalam menumbuhkan jiwa kewirausahaan di kalangan mahasiswa adalah pemberikan pelatihan dan pembinaan mahasiswa mencari dan memecahkan masalah sendiri, program inkubator bisnis masih baru di lingkungan kampus, belum adanya unit bisnis bagi setiap prodi di kampus Akademi Komunitas Negeri Putra Sang Fajar Blitar, sehingga job yang diterima langsung ditangani oleh inkubator bisnis secara serabutan.

\section{REFERENSI}

[1] Agustina, Tri Siwi. 2011. Peranan Inkubator Bisnis Perguruan Tinggi Dalam Meminimalkan Resiko Kegagalan Bagi Wirausaha Baru Pada Tahap Awal (Start-Up). Majalah Ekonomi, 21(1) : 65

[2] Akademi Komunitas Negeri Putra Sang Fajar Blitar. "Sekilas AKN PSF", diakses pada Tanggal 4 April 2019 dari

[3] http://www.akb.ac.id/newakb/tentang/sekilas-akb/

[4] Ali, Utsman. 2015. Teknik Pengumpulan dan Analisis Data Kualitatif, diakses pada Tanggal 6 Januari 2019 dari http://www.pengertianpakar.com/2015/05/teknik-pengumpulan-dananalisis-data-kualitatif.html

[5] Amiaty, Ratna E. 2006. Kajian Inkubator Bisnis dalam Rangka Pengembangan UMKM. Jakarta:Tim Penelitian dan Pengembangan BIRO KREDIT

[6] Amirullah, Imam Hardjanto. 2005. Pengantar Bisnis. Yogyakarta:Graha Ilmu

[7] Boone, Louis E., dan David L. Kurtz. 2007. Pengantar Bisnis Kontemporer, Edisi 11. Jakarta:Salemba Empat

[8] Dantes, Nyoman. 2010. Metode Penelitian. Yogyakarta: C.V Andi Offset

[9] Dasim, Sarnawi M. 2012. Implementasi Pendidikan Karakter Dalam Pembelajaran Sains di Sekolah Dasar. Universitas Pendidikan Indonesia

[10] Eriawaty dan Fitrianty. 2016. Peran Mata Kuliah Kewirausahaan Dalam Menumbuhkan Jiwa Wirausaha Mahasiswa Pendidikan Ekonomi. Jurnal Profit Volume, 3(1) : 24

[11] Hamdani, M. 2010. Entrepreneurship: Kiat Melihat \& Memberdayakan Potensi Bisnis. Jogjakarta:Starbooks 
[12] Kementerian Pendidikan dan Kebudayaan Republik Indonesia. "KBBI Daring", diakses pada tanggal 19 Desember 2018 dari https://kbbi.kemdikbud.go.id/entri/peranan

[13] Maryanti, Sri, Rita Wiyati dan M. Thamrin. 2017. Strategi Menumbuhkan Jiwa Entrepreneur Mahasiswa di Universitas Lancang Kuning. Pekbis Jurnal, 9(3) : 181-182

[14] Maulana, Heri. 2018. Pengembangan Jiwa Kewirausahaan: Studi Kasus Terhadap Mahasiswa yang Berwirausaha di Yogyakarta. Jurnal Ecodemica. 1(2) : 28

[15] Nasution, Arman Hakim, Bustanul Arifin Noer dan Mokh. Suef, 2007.

[16] Entrepreneurship, Membangun Spirit Teknopreneurship. Yogyakarta:C.V ANDI OFFSET

[17] Sarosa, Pietra. 2005. Becoming Young Entrepreneur. Jakarta:PT Elex Media Komputindo

[18] Sattar. 2017. Buku Ajar Pengantar Bisnis. Yogyakarta:Deepublish

[19] Soekanto, Soerjono. 2006. Sosiologi Suatu Pengantar. Jakarta:PT Raja Grafindo Persada

[20] Sukandarrumidi. 2006. Metodologi Penelitian Petunjuk Praktis Untuk Peneliti Pemula. Yogyakarta:Gadjah Mada University Press

[21] Suryana. 2003. Kewirausahaan: Pedoman Praktis, Kiat, dan Proses Menuju Sukses. Jakarta:Salemba Empat

[22] Latifah, N., \& Wardani, S. I. (2019). PENGARUH PROMOSI TERHADAP MINAT BELANJA ONLINE MELALUI KEMAJUAN TEKNOLOGI INTERNET DI KOTA BLITAR. ArRisalah: Media Keislaman, Pendidikan dan Hukum Islam, 17(1), 106-117. 